\title{
Bathymetry Study of the Siltation Level of Lugu Dam Reservoir in Sokoto State, Nigeria
}

\author{
S. J. Ugwu ${ }^{1 *}$, H. N. Ajoge ${ }^{1}$, B. Abdulsalam², M. O. Nwude ${ }^{1}$ \\ ${ }^{1}$ National Water Resources Institute, Mando, Kaduna, Nigeria. \\ ${ }^{2}$ Department of Civil Engineering, Hussaini Adamu Federal Polytechnic, Kazaure, Nigeria.
}

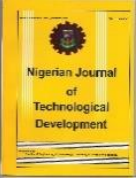

ABSTRACT: This paper seeks to determine the siltation level of the Lugu dam reservoir, Sokoto State, Nigeria, using the bathymetric survey method. A total of eleven (11) ground control points were established over the study area using Hi-Target Global Navigation Satellite (GNS) Real-time Kinematic (RTK) System. The base station was set- up over the reference Bench Mark while the Rover station was moved around to predetermine locations of the ground control points. The depths to the Lugu dam reservoir bed, as well as its underwater topographic mapping with a section of the River Rima on the right flank of the reservoir area, across the collapsed spillway were conducted using Garmin Global Positioning System Map. This was mounted on a nine feet fibre boat to enhance the echo sounding. The result of the study was used to produce a digital elevation model, topographic contours and the area-elevation-capacity curve for the reservoir. This indicates that between elevations $260.5 \mathrm{~m}$ and $262 \mathrm{~m}$, the available minimum and maximum designed storage capacities of Lugu dam reservoir ranges from 21.24 MCM and 34.25 MCM respectively. The Lugu dam reservoir maximum storage capacity at breached level stands at $25 \mathrm{MCM}$, while its active storage capacity is 20 MCM. This is to conclude that the amount of siltation at the reservoir is $9.25 \mathrm{MCM}$ representing $27.01 \%$ indicating the difference between the maximum designed capacity and the current storage capacity. It is recommended that dredging be carried out to regain the initial designed storage capacity as this will no doubt put an end to the incessant flooding and erosion experienced in the area.

KEYWORDS: Lugu dam, siltation, topographic mapping, bathymetric survey, reservoir

\section{INTRODUCTION}

Reservoirs are the basic source of raw water needed for domestic purposes, industrial, agricultural, fishery and other forms of usage. During the dry season, most rural communities in semi-arid regions, solely depend on these reservoirs as a means of survival economically and socially (Loucks and van 2017; Misra, A. K, 2014). Stored water in these facilities (reservoirs) is utilized by farmers during the dry season so as to ensure continued agricultural activities in the absence of the wet season, in order not result in setback, as well bridge the gap on daily demand by the people during the dry season. The constant utilisation of water from these reservoirs in the absence of the wet season helps to remedy the effect of drought (Hermance et al., 2015; Liebe et al., 2005). These reservoirs serve as a means of flood control, as they temporarily retain this water during peak flow, thereby reducing excess surface runoff along the streams contributing downstream (Elkhrachy, 2015; De Coning and Poolman, 2011). It is believed that series of small reservoirs have the capacity to impact greatly on the neighbourhood environment, hydrologically and ecologically (Cantonati et al., 2020; Rodrigues and Liebe, 2013). The effect of these small reservoirs may be optimised to improve the negative impact of climate changes (Krol, et al., 2011). Research indicates that *Corresponding author: ebukush3@gmail.com
$0.5-1 \%$ of reservoirs globally lose their installed capacity due to sediment deposition yearly (Rahmani et al., 2018; Basson, 2009). The continual loss of reservoir capacity due to annual gradual siltation may result in loss of all dam and reservoirs storages by a quarter of their capacities, if necessary actions are not taken, with a projection of fifty years from the year of its report (WCD, 2000).

Data obtained through bathymetric survey, which involves sounding or impulse transmission into water surfaces of dams and reservoirs to obtain xyz coordinates is adequate and remains one of the most reliable components of hydrographic survey and information gathering (Sainson, 2017).

Multiple methods can be used for bathymetric surveys including Multi-Beam and Single-Beam Surveys, Acoustic Doppler Current Profilers (ADCPs), Sub-Bottom Profilers, and the Eco-Mapper Autonomous Underwater Vehicle (EMAUV). Bathymetric surveys allow us to measure the depth of a water body as well as map the underwater features (Menna, et al., 2018)

The emphasis to adopt other advanced methods in the determination of reservoir sediment, such as the application of remote sensing using satellite altimetry may not be applicable independently. This is because other methods other than the bathymetry, do not have the capacity to establish a

doi: http://dx.doi.org/10.4314/njtd.v18i3.8 
baseline needed to estimate the reservoir catchment areas at different elevations. (Erena, et al., 2020; Dost and Mannaerts, 2008). With the application of a bathymetric survey on any dam reservoir, the elevation - area - capacity curve is plotted. The curve produced is an essential tool for reading the capacity of the reservoir at any given cross sectional area and elevation. As such, reservoir professional operators use the result of the curve to interpret the reservoir dam characterization, flood routing, sediment loading and dam reservoir classification (Rodrigues \& Liebe, 2013).

Reservoirs have been widely used for flood control, meeting irrigation water demand, hydroelectric power generation, tourism and maintenance of ecosystem functions (Ainsworth, 2005). But the deposition of sediment in these reservoirs may compromise their initial designed capacities as well as its intended benefits. Reservoir sedimentation primarily is a continuous process that can be unnoticed for a significant portion of the life of a reservoir as silts and other earth material are transported from the upstream river system to downstream of the reservoir with a relatively high sediment transport velocity. The distance of deposition is dependent on decreasing water velocities. Most often the reservoir capacity tends to shrink or reduce with increased deposition and of sediment over time (Radwan, 2016).

The frequent accumulation of silts and sediments may end up producing a normal distribution trend in the reservoir which in most cases affects the reservoir management during peak flood event (Sedlacek, et al., 2016). Fitzpatrick et al, 1987 reported that over a period of 61 years, Lake Decatur lost 9100 acre-feet of storage capacity through increased deposition of sediment to a tonnage of 9,830,000 at the reservoir bed. On average, they estimated each acre of watershed to deliver 21.4 tons of soil material to the lake over the period of study. Chanson and James (2005) had also observed that sedimentation problems were more pronounced in small to medium size reservoirs (catchment area less than $100 \mathrm{~km} 2)$.

Measuring the level of sedimentation and reservoir capacity has been a major challenge in dam management. With the advancement in multi beam technology, echo sounders have become a major instrument in bathymetric surveys (Oke et al., 2019). Acoustic multi-beam systems have proven to be another effective means of hydro survey with series of narrow beam transducers, when mounted on boat is capable of focusing points on or beneath the reservoir water surface (Selva et al., 2013).

Echo sounder bathymetry operates with frequencies between $12 \mathrm{kHz}$ and $500 \mathrm{kHz}$. Joseph et al., (2017), in the survey of Ruiru reservoir, Kenya, deployed dual echo sounder in their bathymetry, and observed different penetrating frequencies ranging between $200 \mathrm{KHz}$ and $350 \mathrm{kHz}$. The implication is that the shorter the wavelength of the signal, the higher the spatial and temporal resolution of the measurements (Jakobsson, et al., 2016; Selva et al., 2013).

The Lugu dam before the collapse of its spillway in 2012 provided a dependable source of water to the Wurno 12,000ha Irrigation Project. The dam is essentially an earth dam with a capacity of 19 million cubic meters of water (NEWMAP,
2019). However, the dam and its other structures are in a dilapidated state, with the spillways, embankment, slopes in various stages of distress. Due to continuous and incessant flooding, the main spillway collapsed in 2012 and the reservoir was reduced to a small and shallow pond of water. This breach has created some deep erosion in the area resulting in the collapse of the existing service spillway. The study seeks to determine the total volume of silts deposited in the reservoir area following series of flooding and dam breach in the reservoir, using bathymetric survey to generate the topographic contour of the study area as well produce the elevation-area-capacity curve for the dam reservoir which will help monitor the maximum capacity of the Lugu dam reservoir.

\section{MATERIALS AND METHODS}

\section{A. Study Area}

The dam is located to the north of Wurno town situated on latitude $13^{0} 20^{\prime} N$ and longitude $4^{0} 55^{\prime} E$, within the Sudan savanna ecological zone on a tributary of the Rima River known as the Balla Creek. It was constructed in the year 1957 by which time the reservoir was being fed by the Balla Creek; extending $6 \mathrm{Km}$ upstream of the Lugu Dam. The flow into the Lugu Dam reservoir at that time was not dependent on the Rima River; but on the small catchment of the Balla Creek. Figure 1 shows the Lugu Dam Reservoir before and after the dam break in 2012. The reservoir is linked to two main canals, namely; Lugu main canal that passes through Lugu village (the site of this study) and Tutudawa main canal that that passes through Tutudawa village, a main drain and a number of secondary canals

\section{B. General Procedure}

The study was carried out with the establishment of eleven (11) ground control points (Table 1) around the reservoir area using the existing bench mark as presented in Table 2. The bathymetric survey of the Lugu dam was done using Garmin Global Positioning System-Map-Chart-plotter - acoustic echo sounding device attached to a nine feet (9ft) fibre boat powered by a 40 horse power Yamaha outboard engine. Topographic mappings at various cross sections of the dam reservoir were conducted. The sounding lines were predetermined and generated over the generated image of the reservoir area and pre-loaded into the navigational GPS which were used to guide the boat navigation during the bathymetry survey. The generated coordinates for the entire survey were used to produce the topographic contour map, digital elevation model and the elevation area capacity curve. While the elevation area capacity curve was plotted using Microsoft Excel. Both the topographic contour map and digital elevation model were produced on geographical information system environment. 


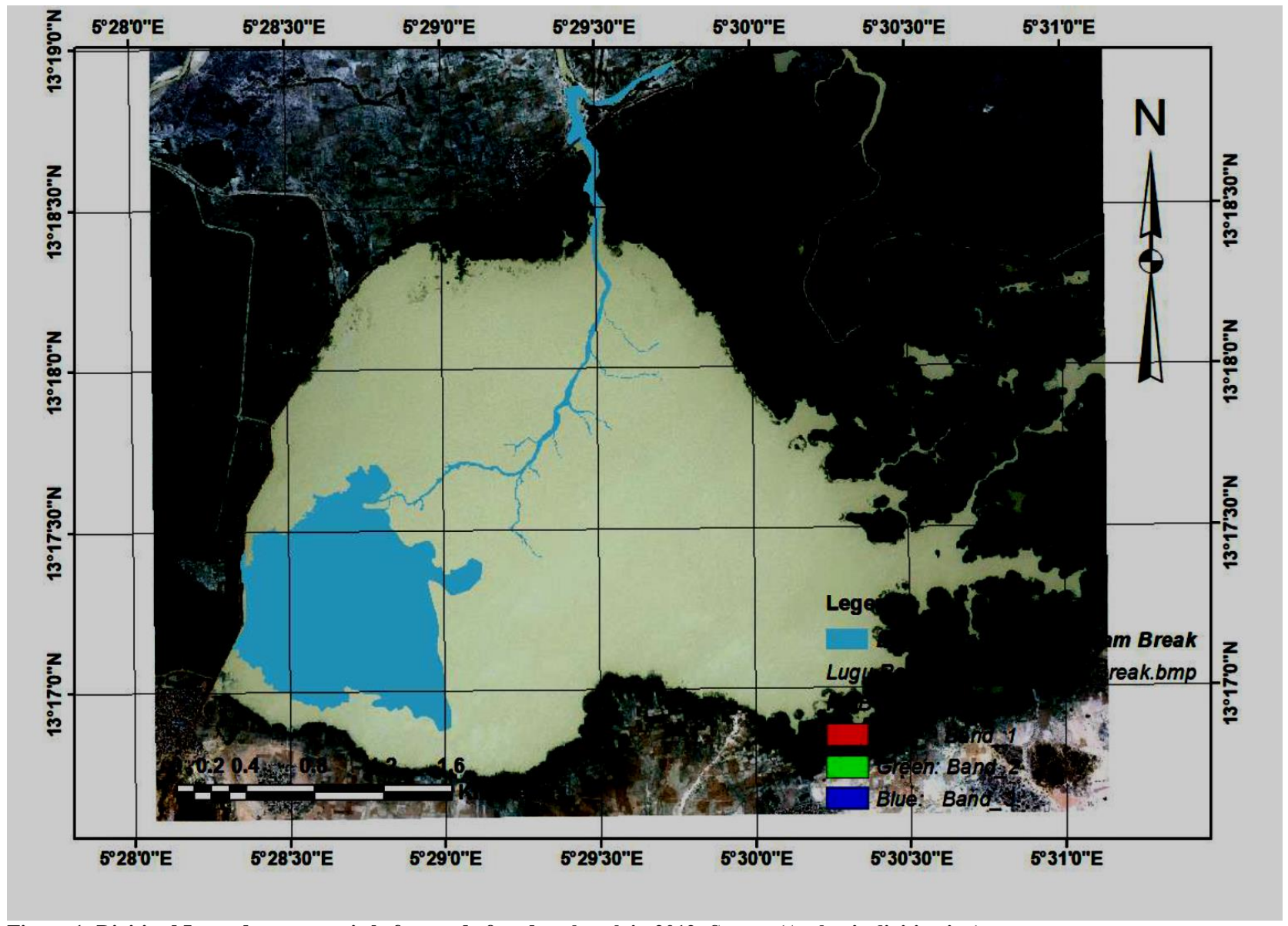

Figure 1: Digitized Lugu dam reservoir before and after dam-break in 2012: Source (Author's digitization).

Table 1: Coordinates of control points with elevations.

\begin{tabular}{llll}
\multicolumn{4}{l}{ Table 1: Coordinates of control points with elevations. } \\
\hline Point Id & Northing & Easting & Elevation \\
\hline GCP04 & 1470925.967 & 767611.034 & 255.863 \\
GCP04A & 1470924.098 & 767610.459 & 255.836 \\
GCP01 & 1472072.035 & 767689.021 & 256.363 \\
GCP01A & 1472072.077 & 767687.017 & 256.287 \\
GCP02 & 1472167.993 & 769184.047 & 257.405 \\
GCP05 & 1471244.977 & 769210.966 & 256.334 \\
GCP05 & 1471246.501 & 769222.716 & 256.435 \\
GCP03B & 1472109.935 & 769973.475 & 256.207 \\
NWRI01 & 1471339.292 & 768015.515 & 258.370 \\
EG WR9 & 1472895.570 & 769748.322 & 260.721 \\
NWRI02 & 1472935.958 & 769759.839 & 259.580 \\
\hline
\end{tabular}

A. Data acquisition using an echo sounder

After successful setting up of the equipment (Figure 2), the echo sounder was turned on as the boat navigates and its data acquisition software (NAV 380) launched. The coordinate system was set at WGS84 (Ketut et al., 2017). The set of the echo sounder was based on the standard operational mode as used by (Ajith, 2016; Selva et al., 2013) where the recording interval was set to 5 seconds while the HIGH and LOWfrequency signal gate, pulse length, and gear were set to AUTO. Under terms menu, the High Frequency (HF) was set to $200 \mathrm{kHz}$, Low Frequency (LF) set to $15 \mathrm{kHz}$ and the penetrating range set to 10 meters for optimum penetration.
Also file menu for the observation was created and saved in order to commence the logging of data and tab clicking. This was based on the principle adopted by Calder and Mayer, 2003).

Table 2: Characteristics of reference bench mark.

\begin{tabular}{ll}
\hline Word Reference; & Remark \\
\hline Easting & $767698.223 \mathrm{E}$ \\
Northing & $1469882.605 \mathrm{~N}$ \\
Elevation & 258.206 amsl \\
Coordinate System & World Geodetic System- 84 (WGS) \\
Description & Beginning of the Lugu Main Canal at \\
& Lugu Village \\
\hline
\end{tabular}

Source: ENPLAN CONSULT GROUP Bench Mark Establishment for Lugu Dam (2019).

The depth of water body was calculated using the principle of acoustic depth measurement as presented in Figure 3 and using Eq. 1 (Parsons, et al., 2013).

$D=\frac{c \Delta t}{2}$

Where $\mathrm{D}$ is the acoustic depth in metre (m), c is the speed of sound in water in metre per second $(\mathrm{m} / \mathrm{s})$ and $t$ is the time of travel of the acoustic pulse to and from the reservoir bed in second (s). The movement of the canoe parallel to the dam was assumed $\mathrm{x}$-axis and the $\mathrm{y}$-axis was its movement perpendicular to the dam. 


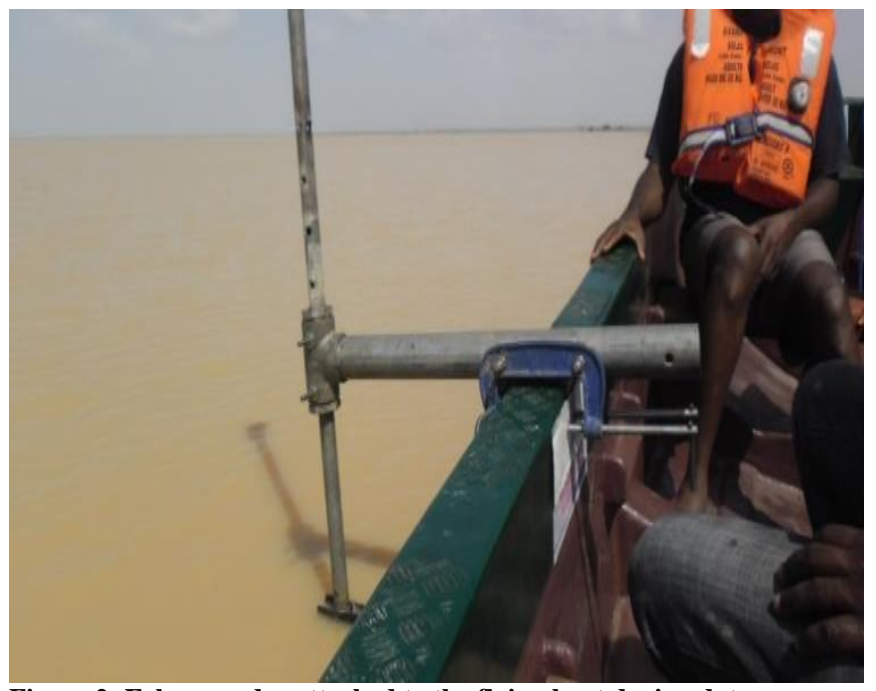

Figure 2: Echo sounder attached to the flying boat during data acquisition.

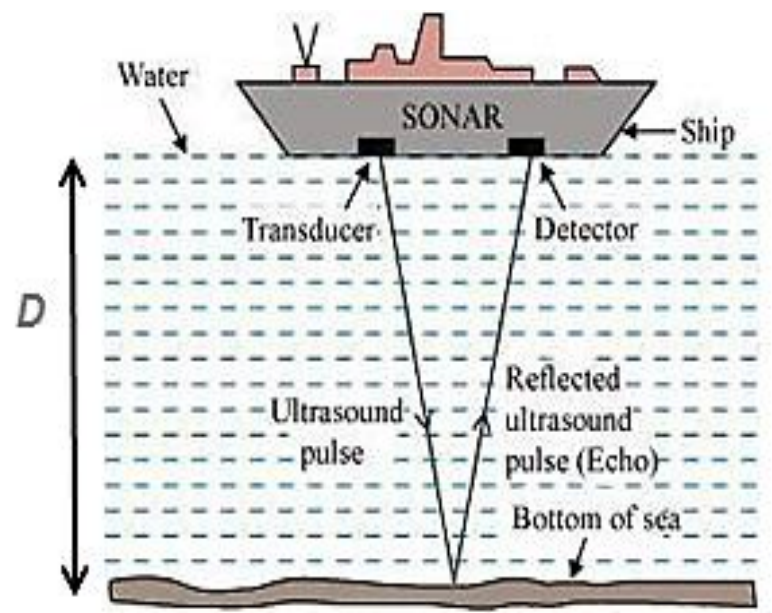

Figure 3: Principle of acoustic depth measurement: Sources: (Arseni et al., 2016).

\section{RESULTS AND DISCUSSION}

The bathymetry survey of Lugu dam reservoir area was conducted based on the sounding at different cross-sections and elevation on the water surfaces, sending impulse to the reservoir bed in the form of xyz coordinates. The data obtained was used to produce the digital elevation models as well as the topographic maps where the contour areas were generated. The transducer attached to the boat measured an average depth of $0.54 \mathrm{~m}$ based on the pulse travel time and velocity. The depth obtained from the transducer $(0.54 \mathrm{~m})$ is an indication of the shallow nature of the reservoir. Processing the Digital Elevation Model (DEM) in ArcGis environment, a bathymetric map of the reservoir and depth-area-volume curve was obtained (Figure 4). The result indicates that the existing embankment crest elevations varies between $261 \mathrm{~m}$ to $263 \mathrm{~m}$ above mean sea level (amsl) while existing archived satellite imageries downloaded from Global Mapper and United States Geological Survey (USGS) shows that the maximum reservoir shoreline before the dam breach was at elevation of $260 \mathrm{~m}$ amsl. Triangular Irregular Network (TIN) generated from the Digital Elevation Model (DEM) was used to produce the surface topography of the reservoir area. The curve shows that between elevations $260.5 \mathrm{~m}$ and $262 \mathrm{~m}$, the available minimum and maximum storage capacities of Lugu dam reservoir ranges from 21.24 MCM (Million Cubic Metre) and 34.25 MCM (Million Cubic Metre) respectively. The current active storage capacity (20 MCM) is less than the minimum and maximum designed capacities by $6.2 \%$ and $71.25 \%$ respectively, indicating silt deposition. This is an indication of silt deposition.

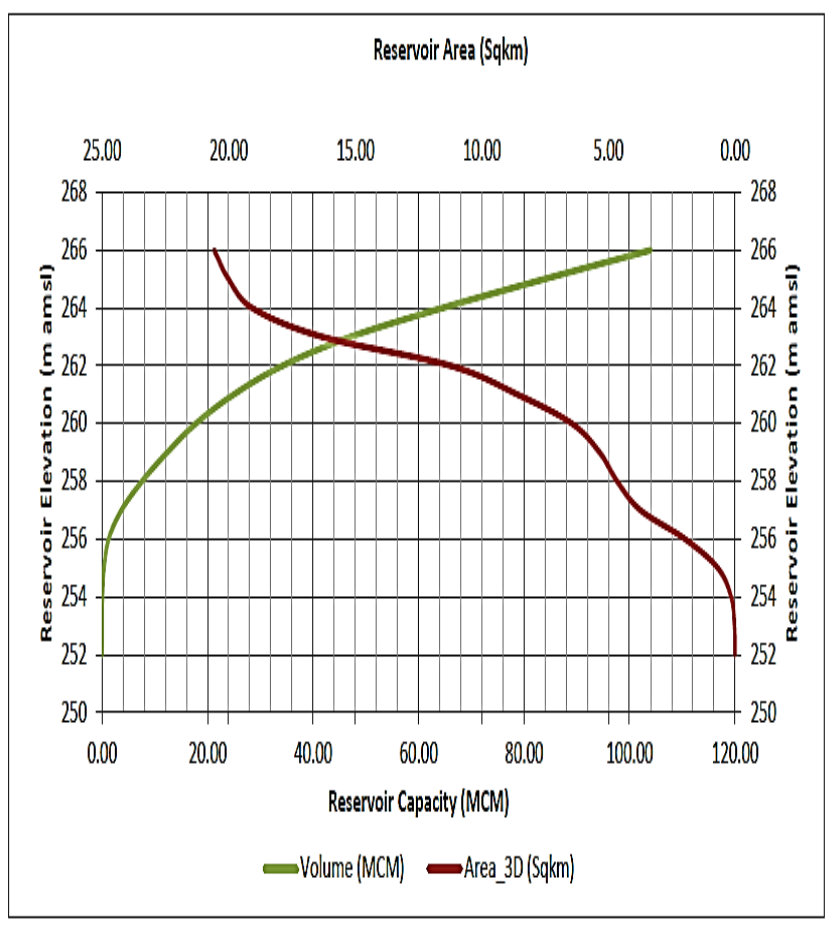

Figure 4: Lugu dam reservoir area-elevation-capacity curve.

The extent of the bathymetric survey on Lugu dam reservoir is presented in Figure 5. This shows the navigation line of the boat during the bathymetry, while the topography of the Lugu dam reservoir and environ with the surface contour generated as captured by the bathymetry is presented in Figures 6 and 7 respectively.

Digital Elevation Model (DEM) was converted to Triangular Irregular Network (TIN), a vector-based digital geographic data which helped in the presentation of the reservoir surface morphology and in the calculation of planimetric area, surface area and volume. During the bathymetry surveys, depths to reservoir bed were automatically streamed and recorded into the memory of the echo sounder by the transducer installed at a draft distance of $0.1 \mathrm{~m}$ below the water surface using the principles of echo sounding as shown in figure 2 above. Horizontal positions of all sounding data were referenced to the World Geodetic System Datum of 1984 (WGS 1984) using the Universal Transverse Mercator (UTM) projection Zone 31N. 


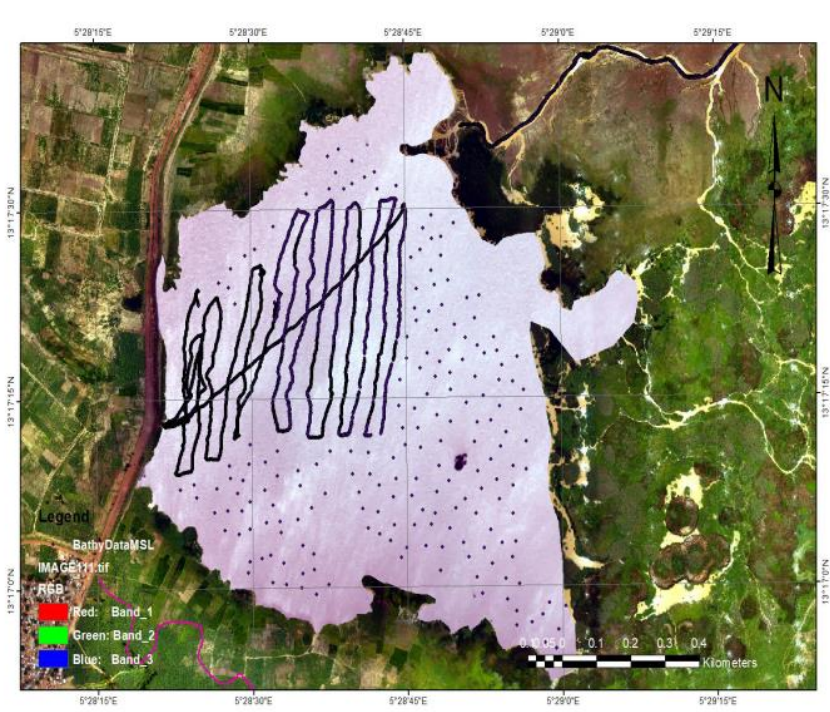

Figure 5: The extent of bathymetry survey over Lugu dam reservoir. 5027'30"E $\quad 5^{\circ} 28^{\prime} 0^{\circ} \mathrm{E} \quad 5^{\circ} 28^{\prime} 30^{\prime \prime} \mathrm{E} \quad 5^{\circ} 29^{\prime} 0^{\prime \prime} \mathrm{E} \quad 5^{\circ} 29^{\prime} 30^{\prime \prime} \mathrm{E} \quad 5^{\circ} 30^{\prime} 0^{\prime \prime} \mathrm{E} \quad 5^{\circ} 30^{\prime} 30^{\prime \prime} \mathrm{E} \quad 5^{\circ} 31^{\prime} 0^{\prime \prime} \mathrm{E} \quad 5^{\circ} 31^{\prime} 30^{\prime \prime} \mathrm{E}$

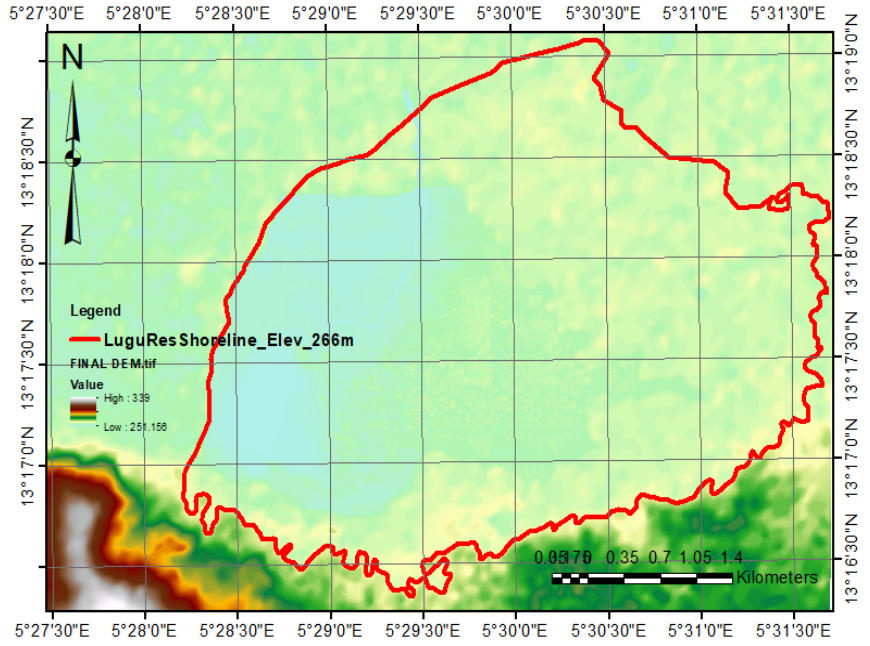

Figure 6: Digital elevation model of Lugu dam reservoir area and environ.

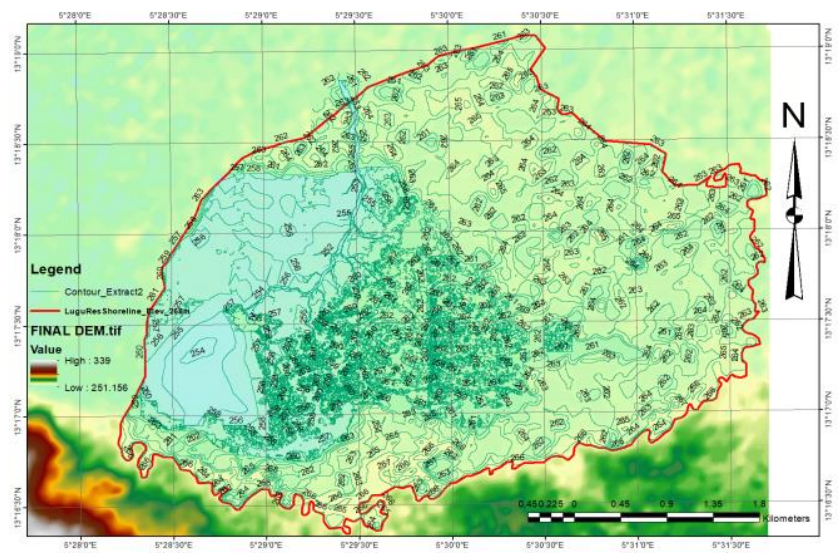

Figure 7: Topographic contours of Lugu dam reservoir area.

\section{CONCLUSION}

The bathymetric survey of Lugu dam reservoir shows that active storage capacity of the reservoir is far less than the minimum and the maximum designed capacities by $6.2 \%$ and $71.25 \%$ respectively and, this is an indication of high silt deposition and loss of storage volume. The Lugu dam reservoir maximum storage capacity at breached level stands at $25 \mathrm{MCM}$ while its active storage capacity is $20 \mathrm{MCM}$. This is to conclude that the amount of siltation at the reservoir is 9.25 MCM representing $27.01 \%$ indicating the difference between the maximum designed capacity and the current storage capacity. It is recommended that rehabilitation of the dam should be focused at the elevations where the maximum and minimum capacities are expected based on the initial design. Also dredging should be carried out to regain the initial designed storage capacity, this will no doubt put an end to the incessant flooding and erosion experienced in the area.

\section{REFERENCES}

Ainsworth, R.G. (2005). World Water Storage in ManMade Reservoirs. Foundation for Water Research, Bucks, SL7 IFD, UK

Ajith, A. V. (2016). Bathymetric Survey to Study the Sediment Deposit in Reservoir of Peechi Dam. Proceeding of the International Conference on Emerging Trends in Engineering and Management, 3(1): 34-38

Arseni, M.; A. Roșu.; L. P. Georgescu; and G. Murariu. (2016). Single Beam Acoustic Depth Measurement Techniques and Bathymetric Mapping for Catusa Lakegalati. Annals of the University Dunarea de Jos of Galati: Fascicle II, Mathematics, Physics, Theoretical Mechanics, 8(2): 281-287

Basson, G. R. (2009). Management of siltation in existing and new reservoirs. General Report. 89. Proc. of the $23^{\text {rd }}$ Congress of the Int. Commission on Large Dams CIGBICOLD (vol. 2) Conf. 51-52

Calder, B. R. and L.A. Mayer. (2003). Automatic Processing of High-rate, High-density Multi Beam Echo sounder Data. Geochemistry Geophysics Geo-systems, 4(6): $1048-1060$.

Cantonati, M.; S. Poikane.; C.M Pringle.; L.E. Stevens.; E. Turak.; J. Heino and M. Ctvrtlíková. (2020). Characteristics, main impacts, and stewardship of natural and artificial freshwater environments: Consequences for biodiversity conservation, 12(1): 260-265.

Chanson, H. and D.P. James. (2005). Siltation of Australian Reservoirs: Some Observations and Dam Safety Implications. Department of Civil Engineering, the University of Queensland, Brisbane QLD4072, Australia, 13(2):55-63.

Chanson, H. and P. James. (1998). Rapid Reservoir Sedimentation of Four Historic Thin Arch Dams in Australia.Journal of Performance of Constructed Facilities, ASCE, 12 (2): 85-92.

Das, S. K.; R.K. Gupta and H.K. Varma. (2007). Flood and Drought Management through Water Resources Development in India. Bulletin of the World Meteorological Organization, 56(3): 179-188.

De Coning, E. and E. Poolman. (2011). South African Weather Service Operational Satellite based Precipitation 
Estimation Technique: Applications and Improvements. Hydrology and Earth System Sciences, 15(4): 1131-1145.

Dost, R. J. J. and C.M.M. Mannaerts. (2008). Generation of Lake Bathymetry using Sonar, Satellite Imagery and GIS. In Proceedings of the 2008 ESRI International user Conference: GIS, Geography in action. San Diego, Florida, 40(4): 981-997.

Elkhrachy, I. (2015). Flash Flood Hazard Mapping using Satellite images and GIS tools: a case study of Najran City, Kingdom of Saudi Arabia (KSA). The Egyptian Journal of Remote Sensing and Space Science, 18(2): 261-278.

Erena, M.; J.A. Domínguez.; J.F. Atenza.; S. GarcíaGaliano.; J. Soria and A. P. Ruzafa. (2020). Bathymetry Time Series Using High Spatial Resolution Satellite Images, 12(2): 531-536.

Fitzpatrick, W. P.; W.C. Bogner and N.G. Bhowmik. (1987). Sedimentation and hydrologic processes in Lake Decatur and its watershed. Illinois State Water Survey, 4(7):234-239.

Hermance, J. F.; D.J. Augustine and J.D. Derner. (2015). quantifying characteristic growth dynamics in a semiarid grassland ecosystem by predicting short-term NDVI phenology from daily rainfall: a simple four parameter coupled-reservoir model. International Journal of Remote Sensing, 36(22): 5637-5663.

Jakobsson, M.; R. Gyllencreutz; L.A. Mayer; J.A. Dowdeswell; M. Canals; B.J. Todd and R.D. Larter. (2016). Mapping submarine glacial landforms using acoustic methods. Geological Society, London, Memoirs, 46(1): 1740 .

Joseph, K. S.; M.R. James; M.M. Bancy; N.M. Urbanus and O. Franklin. (2017). Duel Echo Sounder Bathymetric Survey for Enhance Management of Ruiru Reservoir, Kenya. Journal of Sustainable Research, 3(4): 113 118.

Ketut T. S.; K. Hairi; H.G. Putu and P. Hery. (2017). Small Rov Marine Boat for Bathymetry Surveys of Shallow Waters Potential Implementation in Malaysia. The International Archives of the Photogrammetry, Remote Sensing and Spatial Information Sciences, Volume XLII4/W5, (2017) GGT, 201-208.

Liebe, J.; N. Van De Giesen and M. Andreini. (2005). Estimation of small reservoir storage capacities in a semi-arid environment: A case study in the Upper East Region of Ghana. Physics and Chemistry of the Earth, Parts $A / B / C$, 30(6-7): 448-454.

Loucks, D. P. and E. van Beek. (2017). Water resources planning and management: An overview. In Water Resource Systems Planning and Management.1-49.

Mahmood, K. (1987). Reservoir sedimentation: Impact, Extent, and Mitigation (Tech. Rep. No. 5). International Bank for Reconstruction and Development, Washington, DC, USA

Menna, F.; P. Agrafiotis and Georgopoulos, A. (2018). State of the art and applications in archaeological underwater
3D recording and mapping. Journal of Cultural Heritage, 33: 231-248.

Misra, A. K. (2014). Climate change and Challenges of Water and Food Security. International Journal of Sustainable Built Environment, 3(1): 153-165.

NEWMAP (2019): A Report by Nigeria Watershed Management Project on Environmental and Social Impact Assessment for the Rehabilitation of Lugu Earth Dam Sokoto State, Nigeria

Oke, A. O.; K. Ogedengbe and A.S. Ajani. (2019). A Comparison of different methods for Bathymetric Survey and Sedimentation Evaluation of a Small Reservoir in Nigeria for Sustainable Management. Journal of Agriculture and Environment for International Development (JAEID), 113(2): 181-195.

Parsons, D. R.; P.R. Jackson; J.A. Czuba; F.L. Engel; B.L. Rhoads; K.A. Oberg and J.D. Riley. (2013). Velocity Mapping Toolbox (VMT): A processing and visualization suite for moving-vessel ADCP measurements. Earth Surface Processes and Landforms, 38(11): 1244-1260.

Radwan, A.E. and E. Tarek. (2016). Bathymetric Study of Some Khors in Lake Nasser, Egypt. Lakes, Reservoirs and Ponds, 10(2): 139-158.

Radwan G. E. A. (2016). Bathymetric Study of Wadi ElRayan Lakes, Egypt. Lakes, Reservoirs and Ponds, 10(2): 110-125.

Rahmani, V.; J.H. Kasten; F. DeNoyelles; M.E. Jakubauskas; E.A. Martinko; D.H. Huggins and A.J. Blackwood. (2018). Examining Storage Capacity loss and Sedimentation rate of Large Reservoirs in the Central US Great Plains. Water, 10(2): 190.

Rodrigues, L. N. and J. Liebe. (2013). Small Reservoirs depth-area-volume relationships in Savannah Regions of Brazil and Ghana. Water Resources and Irrigation Management-WRIM, 2(1): 1-10.

Sainson, S. (2017). Principles and Methods. In Electromagnetic Seabed Logging. 51-129

Sedlacek, J.; O. Bábek and O. Kielar. (2016). Sediment accumulation rates and high-resolution stratigraphy of recent fluvial suspension deposits in various fluvial settings, Morava River catchment area, Czech Republic. Geomorphology.254: 73-87.

Selvan M. B.; D. Arnab; K. Madhur and C. Piyush. (2013). A Review of Various Technologies for Depth Measurement in Estimating Reservoir Sedimentation International Journal of Engineering Research and Technology. 2(10): 223228.

Smith W. H. F. (1993). On the Accuracy of Digital Bathymetric Data. Journal of Geophysical Research, 98(B6): 9591- 9603.

WCD. (2000): The Report of the World Commission on Dams. London: World Commission on Dams/Earth Scan Publications. 